\title{
Optimalisasi hasil belajar siswa melalui remedial teaching
}

\author{
Rizky Diana Shafitra ${ }^{1)}$, Dian Renata ${ }^{2 *}$, Dewi Purwaningsih ${ }^{3)}$ \\ 1,2,3) Universitas Indraprasta PGRI \\ *) dianrenata66@gmail.com
}

Article History: Received: 08/04/2021; Revised: $17 / 05 / 2021$; Accepted: 11/06/2021; Published: 28/06/2021.

How to cite: Shafitra, R.D., Renata, D., \& Purwaningsih, D. (2021). Optimalisasi hasil belajar siswa melalui remedial teaching. Orien: Cakrawala Ilmiah Mahasiswa, 1(1) pp. 81-86. DOI:

10.30998/ocim.v1i1.4576

\section{(c) (i) This is an open} access article distributed under the Creative Commons 4.0 Attribution License, which permits unrestricted use, distribution, and reproduction in any medium, provided the original work is properly cited. (C) 2021, Shafitra, R.D., Renata, D., \& Purwaningsih, D.

\begin{abstract}
Abstrak: Penelitian ini bertujuan untuk melihat sumbangsih remedial teaching untuk mengoptimalkan hasil belajar siswa. Penelitian ini merupakan penelitian kualitatif dengan jenis deskriptif. Data dikumpulkan melalui wawancara, observasi, dan catatan dokumentasi. Sumber data dalam penelitian ini diperoleh dari wali kelas, guru bimbingan dan konseling, guru mata pelajaran, dan tiga orang siswa. Data dianalisis dengan menggunakan teknik triangulasi. Hasil penelitian ini adalah remedial teaching mampu mengoptimalkan hasil belajar.
\end{abstract}

Kata Kunci: hasil belajar, remedial teaching

Abstract: This study aim to determine role of remedial teaching to optimize learning outcomes of students. This was a qualitative research with descriptive type. Data were collected by interview, observation, and documentation. The resource of data from homeroom teacher, guidance and counseling teacher, field study teacher, and three students. Data were analyzed by triangulation technique. The result shown that remedial teaching could to optimize students learning outcome.

Keywords: learning outcome, remedial teaching

\section{Pendahuluan}

Keberhasilan seorang siswa yang belajar dapat dilihat keberhasilannya dalam hasil belajar melalui tes hasil belajar. Hasil yang diharapkan adalah prestasi belajar yang baik karena setiap orang menginginkan prestasi yang tinggi, baik siswa, guru, sekolah, maupun orang tua hingga masyarakat. Namun antara siswa satu dengan siswa yang lainnya memiliki perbedaan dalam pencapaian prestasi belajar. Ada yang mampu mencapai prestasi yang tinggi, namun ada juga siswa yang rendah hasil belajarnya.

Menurut Slameto (2003) inteligensi anak merupakan potensi bawaan yang sering dikaitkan dengan berhasil tidaknya anak belajar di sekolah. Dengan kata lain intelegensi dianggap sebagai faktor yang menentukan berhasil tidak nya anak belajar di sekolah. Dalam perspektif psikologis, intelegensi dianggap sebagai kemampuan mental seseorang dalam merespon dan menyelesaikan problem-problem dari yang bersifat kuantitatif dan fenomenal. Dengan mengetahui intelegensinya,seseorang dapat dikategorikan sebagai orang yang pandai atau memiliki daya fikir yang cepat dan tepat atau daya fikir yang lambat.

Selain faktor inteligensi siswa, hasil belajar itu dapat ditingkatkan dengan adanya kegiatan remedial teaching yang dilaksanakan oleh guru. Remedial Teaching itu memberikan 
harapan baik kepada siswa atau siswa yang mengalami kesulitan belajar. Menurut Shalahuddin (Mulyadi, 2010) suatu kegiatan yang sama yang dilakukan secara berulang-ulang bertujuan untuk memperkuat suatu asosiasi atau menyempumakan suatu keterampilan agar menjadi permanen.

Pembelajaran remedial teaching ini pada dasarnya ditunjukkan untuk meningkatkan kuantitas siswa dan kualitas masing-masing siswa dalam menguasai materi pelajaran. Dengan demikian, siswa yang masih perlu meningkatkan ketuntasan belajarnya pada topik-topik tertentu merupakan sasaran secara umum pembelajaran remedial teaching ini. Sehingga dapat dikatakan juga bahwa, pembelajaran remedial teaching sebagai upaya pengayaan pemahaman siswa, bukan pembelajaran untuk anak yang tidak pintar.

Pengajaran remedial sifatnya lebih khusus karena disesuaikan dengan karakteristik kesulitan belajar yang dihadapi siswa. Pengajaran remedial merupakan suatu bentuk pengajaran yang bersifat mengobati, menyembuhkan, atau membetulkan pengajaran dan membuatnya menjadi lebih baik dalam rangka mencapai tujuan pengajaran yang maksimal (Mulyadi, 2008). Pengajaran remedial yang bersifat menyembuhkan atau pembetulan pengajaran seperti melakukan bantuan kepada siswa yang mendapatkan nilai rendah dapat melaksanakan remedial untuk ke arah yang lebih baik dalam mencapai tujuan pembelajaran yang maksimal yaitu nilai yang dicapai lebih baik sebelum dilakukan remedial.

Remedial teaching sangat diperlukan dalam proses belajar mengajar, beberapa alasan perlunya remedial teaching dapat dilihat dari berbagai segi. Pertama dari peserta didik, kenyataan menunjukkan bahwa masih banyak siswa yang belum dapat mencapai prestasi belajar yang diharapkan. Hal ini ditunjukkan dari hasil belajar peserta didik yang masih di bawah standar Kriteria Ketuntasan Minimal (KKM). Kedua, dari pihak guru, pada dasarnya guru bertanggang jawab atas keseluruhan proses pendidikan di sekolah. Ini berarti bahwa guru bertanggung jawab akan tercapainya tujuan pendidikan melalui pencapaian tujuan instruksional dan tujuan kurikuler. Ketiga, dilihat dari segi pengertian proses belajar, remedial diperlukan untuk melaksanakan proses belajar sebenarnya, proses belajar yang sesungguhnya ditandai dengan perubahan tingkah laku secara keseluruhan. Adanya gejala kesulitan belajar merupakan salah satu gambaran belum tercapainya perubahan tingkah laku secara keseluruhan. Oleh karena itu, masih diperlukan proses belajar mengajar khusus yang dapat membantu pencapaian perubahan tingkah laku sebagai hasil belajar. Dalam hubungan ini remedial merupakan salah satu usaha tersebut. Keempat, pelaksanaan pelayanan bimbingan dan penyuluhan di sekolah pada dasarnya merupakan salah satu unsur dalam keseluruhan proses pendidikan. Melalui pelayanan bimbingan dan penyuluhan, setiap peserta didik akan mendapatkan pelayanan pribadi sehingga peserta didik dapat memahami diri dan mampu mengarahkan dirinya optimal (Ahmadi, 2004).

Dapat disimpulkan bahwa perlunya remedial teaching dapat dilihat dari empat pandangan yang berbeda baik dari peserta didik, guru, proses belajar, dan pelaksanaan pelayanan bimbingan dan penyuluhan di sekolah. Penerapan remedial teaching tidak lepas dari peserta didik atau siswa yang mengalami proses pembelajaran baik secara langsung dan tidak langsung berkaitan dengan kegiatan perbaikan yang dilakukan dalam rangka proses belajar mengajar yang menganut prinsip belajar tuntas. Kegiatan pengayaaan dan kegiatan perbaikan merupakan dua kegiatan yang sama pentingnya.

Dengan menerapkan remedial teaching mempunyai tujuan dalam proses pemberian bantuan dalam mengatasi ketinggalan belajar siswa yang lamban dan sukar menerima pelajaran, maka diperlukan bantuan belajar untuk siswa agar segala sesuatu yang menghalangi proses remedial teaching dapat dikurangi atau ditingkatkan sesuai dengan harapan dan cita-cita yang 
harus dicapai oleh seorang pendidik baik dalam mata pelajaran umum maupun pelajaran matematika khususnya.

Berbagai macam permasalahan selalu muncul ketika pembelajaran Matematika berlangsung, masih banyaknya siswa yang kurang memiliki kemampuan memahami penjelasan rumus dan fungsi yang benar. Walaupun sudah mampu dalam membaca dan menghafal rumusnya tetapi penerapan dalam latihan-ujian masih kurang. Hal ini menuntut siswa disamping harus mempunyai kemampuan dalam menyerap, memahami, dan mengimplementasikan, juga sebagai upaya dalam meningkatkan kemampuan dan pemahaman siswa terhadap materi pembelajaran matematika sangat diperlukan pembelajaran tambahan dan penambahan jam pelajaran diluar jam.

Berdasarkan wawancara yang dilakukan kepada guru mata pelajaran matematika bahwa pengajaran remedial dalam pelaksanaannya akan mengalami perbedaan konsep sesuai dengan taraf kesulitan yang dihadapi siswa dalam memahami dan mengerti materi pelajaran, terutama pada mata pelajaran matematika. Masih ada beberapa anak yang kurang mampu menguasai teknik menghitung dalam pelajaran matematika, sebagian siswa menganggap pelajaran matematika cukup sulit karena hasil yang sulit didapatkan walaupun sudah memakai cara atau rumus yang sama.

Dalam hal ini Remedial Teaching sangat diperlukan dalam meningkatkan prestasi belajar siswa khususnya pada mata pelajaran matematika dan pelajarannya lainnya bila diperlukan Remedial Teaching. Berdasarkan fakta-fakta tersebut maka melalui penelitian ini akan dilihat apakah hasil belajar siswa mampu dioptimalkan melalui remedial teaching. Tujuan penelitian ini untuk memperoleh informasi dan gambaran menyeluruh tentang peran remedial teaching terhadap hasil belajar siswa kelas XI di SMA 5 BOGOR.

\section{Metode}

Pendekatan yang di gunakan pada penelitan ini adalah pendekatan penelitian kualitatif yaitu dengan mencari makna, pemahaman, pengertian, tentang suatu venomena, kejadian, maupun kehidupan manusia denga terlibat langsung dan/atau tidak langsung dalam setting yang diteliti, kontekstual, dan menyeluruh. Peneliti bukan mengumpulkan data sekali jadi atau sekaligus dan kemudian mengolahnya, melainkan, tahap demi tahap dan makna disimpulkan selama proses berlangsung dari awal sampai akhir kegiatan, bersifat naratif, dan holistik. Sugiyono (2010) menjelaskan bahwa metode penelitian kualitatif merupakan metode penelitian yang berlandaskan pada filsafat positivisme, digunakan untuk meneliti pada kondisi obyek yang alamiah, (sebagai lawannya adalah eksperimen) dimana peneliti adalah sebagai instrumen kunci, pengambilan sampel sumber data dilakukan secara purposive dan snowbaal, teknik pengumpulan dengan triangulasi, analisis data bersifat induktif/kualitatif, dan hasil penelitian kualitatif lebih menekan makna dari pada generalisasi.

Teknik penelitian yang digunakan dalam penelitian ini adalah menggunakan kualitatif deskriptif, karena penelitian ini ingin mengetahui tentang fenomena yang ada dan dalam kondisi yang alamiah, bukan dalam kondisi terkendali, atau eksperimen. maka peneliti berharap untuk dapat mengetahui peran remedial teaching terhadap hasil belajar siswa kelas XI di SMA Negeri 5 Bogor dan implementasinya dalam Bimbingan dan Konseling. Penelitian ini dilakukan di SMAN 5 Bogor yang dilakukan selama kurang lebih empat bulan terhitung dari bulan April hingga bulan Juli 2020. Sumber data dalam penelitian ini dibagi menjadi dua yaitu sumber data primer dan sumber data sekunder. Yang termasuk dalam sumber data primer dalam penelitian ini 
adalah warga sekolah yang meliputi; wali kelas, guru Bimbingan dan Konseling, siswa yang mengikuti remedial teaching dan guru mata pelajaran matematika. Sumber data sekunder dalam penelitian ini yaitu melalui studi kepustakaan, nilai nilai siswa dan bahan ajar.

Teknik pengumpulan data pada penelitian ini adalah wawancara, observasi dan studi dokumentasi. Peneliti mendapatkan informasi langsung dengan teknik wawancara dari wali kelas, guru BK dan guru mata pelajaran matematika. Sedangkan Observasi yang dilakukan peneliti adalah melihat, meneliti dan melakukan pencatatan terhadap hal yang terkait dengan siswa yang memiliki nilai rendah sehingga membutuhkan remedial teaching. Dokumentasi yang dikumpulkan oleh peneliti adalah nilai nilai siswa dan bahan ajar. Teknik analisis data dalam peneltian kualitatif menggunakan metode Miles \& Huberman (2005) yang meliputi pengumpulan data, reduksi data, dan verifikasi data. Data diabsahkan melalui teknik triangulasi data.

\section{Hasil dan Diskusi}

Dalam dunia pendidikan, kegiatan penilaian hasil belajar merupakan suatu bagian yang sangat penting. Hal ini tidak hanya karena penilaian merupakan bagian dalam proses pendidikan, tetapi terlebih juga karena terkait dengan proses pengukuran, pengukuran ini merupakan tahap dalam proses akhir pendidikan sekaligus merupakan usaha untuk mengetahui efektivitas pendidikan melalui hasil belajar siswa. Melalui hasil belajar dapat diketahui seberapa besar kesiapan siswa dalam mengahdapi masa depan yang akan datang, baik dari dunia pendidikan maupun dalam dunia kerja ketika sudah bermasyarakat. Hasil belajar merupakan perubahan tingkah laku yang dialami seseorang (siswa) setelah melakukan kegiatan belajar, dan hasil belajar ini dapat diukur dengan nilai yang didapatkan setelah melakukan proses pembelajaran. Hasil belajar merupakan hasil dari suatu interaksi tindak belajar dan tindak mengajar (Syah, 2012). Dari sisi guru, tindak mengajar diakhiri dengan proses evaluasi hasil belajar. Dari sisi siswa, hasil belajar merupakan berakhirnya proses belajar. Dari pendapat di atas, dapat diketahui hasil belajar merupakan interaksi antara siswa dan guru dalam proses belajar dan mengajar hasil belajar yang diberikan guru merupakan tahap evaluasi untuk menguji keberhasilan dalam proses belajar siswa yang tertuang dalam bentuk angka dan akan disampaikan kepada orang tua berbentuk raport. Sedangkan untuk siswa, hasil belajar merupakan puncak tertinggi dalam kegiatan belajar selama ini, untuk menguji sejauh mana daya tangkap siswa.

Dalam pencapaian hasil belajar yang diharapkan peran remedial teaching dapat membantu siswa yang gagal dalam mencapai ketuntasan belajar yang dilihat dari pencapaian hasil belajar yang maksimal. Remedial teaching yaitu suatu proses kegiatan pelaksanaan program belajar mengajar khusus bersifat individual, diberikan kepada siswa yang mengalami gangguan belajar tersebut sehingga dapat mengikuti proses belajar mengajar secara klasikal kembali untuk mencapai prestasi optimal (Sugiyanto, 2007). Pembelajaran remedial diberikan kepada murid yang mengalami gangguan belajar secara khusus, pembelajaran yang diberikan dapat berupa tambahan waktu untuk membahas kembali pembelajaran yang diikuti dikelas, dan pemisahan kelas untuk membahas materi terkait yang membutuhkan remedial.

Berdasarkan hasil penelitian yang telah dilakukan diketahui bahwa berdasarkan hasil wawancara dalam penelitian ini dilakukan kepada guru BK, wali kelas XI, guru matematika, dan tiga siswa yang memiliki nilai rendah pada mata pelajaran matematika. Melalui pertanyaan wawancara yang telah disiapkan oleh peneliti. Pertanyaan yang disiapkan sesuai dengan 
indikator dan kisi-kisi yang telah disetujui oleh dosen pembimbing materi dan teknik. Adapun subjek penelitian adalah N sebagai guru matematika, T sebagai wali kelas XI, P sebagai guru BK dan $\mathrm{W}$, E, dan $\mathrm{C}$ sebagai siswa yang memiliki nilai rendah pada mata pelajaran matematika.

Sehingga dari hasil wawancara dapat dianalisis bahwa dari remedial teaching dapat berpengaruh terhadap hasil belajar siswa melalui perubahan sikap. Artinya, siswa yang selalu melakukan remedial teaching masih merasa kurang paham dengan beberapa materi yang diberikan oleh guru sehingga harus melaksanakan remedial, namun dengan adanya remedial membuat mereka paham dengan letak kelemahan mereka dalam memahami materi dan membuat mereka tetap berusaha bertanya pada teman nya jika ada materi yang kurang dikuasai.

Semua subjek yang diwawancarai punya cara sendiri dalam menyesuaikan diri dalam belajar. Dua dari tiga siswa yang diwawancarai oleh peneliti lebih memilih bertanya kepada teman terkait materi yang dirasa kurang dipahami. Sedangkan satu orang lainnya mengatakan bahwa dirinya lebih mampu memahami materi sendiri dengan memanfaatkan media yang ada.

Sedangkan dari hasil observasi yang ada dapat di simpulkan bahwa kondisi lingkungan sekolah sudah cukup baik dan nyaman sehingga siswa pun merasa nyaman saat proses belajar berlangsung. Kebersihan sekolah pun sangat terjaga dengan ada nya tempat pembuangan sampah yang di sediakan dan fasilitas yang ada sudah cukup memadai dan berguna untuk siswa maupun staf sekolah lainnya.

Dalam penelitian ini terdapat kekurangan atau keterbatasan yang dimiliki oleh penulis diantaranya situasi dan kondisi pada saat penelitian ini dilakukan yaitu masa awal pandemi dan kurang maksimalnya dalam menggali data yang ada, sehingga diharapkan saran bagi peneliti lain yang ingin melakukan penelitian serupa agar menambah jumlah subjek agar memperkaya data yang didapatkan. Selain itu, para peneliti juga diharapkan dapat memperhatikan pemilihan kosa kata yang tepat dalam wawancara. Sebisa mungkin menggunakan kosa kata yang sederhana namun memiliki padanan kata dan kesetaraan makna yang dimaksudkan oleh peneliti.

\section{Simpulan}

Berdasarkan hasil penelitian yang dilakukan penulis tentang Peran Remedial Teaching terhadap hasil belajar siswa kelas XI dan implikasinya terhadap bimbingan dan konseling di SMA Negeri 5 Bogor dapat ditarik kesimpulan bahwa remedial teaching belum memiliki pengaruh yang terlalu signifikan terhadap hasil belajar. Namun, dengan adanya remedial teaching dapat mengubah sikap siswa menjadi lebih perduli terhadap cara belajar sehingga terdapat perubahan di hasil akhir pelajaran. Implikasi Bimbingan dan Konseling terhadap remedial teaching dalam rangka mengatasi permasalahan belajar yang dimiliki oleh tiap siswa telah dilakukan dengan baik oleh guru Bimbingan dan Konseling dan disesuaikan dengan kebutuhan masing-masing siswa.

\section{Ucapan Terima Kasih}

Dalam pelaksanaan penelitian ini, penulis tidak lepas dari bantuan dan bimbingan berbagai pihak. Oleh karena itu penulis ingin menyampaikan terima kasih kepada semua pihak yang tidak bisa saya tuliskan satu persatu. Semoga amal kebaikannya berbalas pahala berlipat ganda dari Tuhan Yang Maha Kuasa. 
86 Optimalisasi hasil belajar siswa melalui remedial teaching

\section{Daftar Rujukan}

Ahmadi, A. (2004). Psikologi Pendidikan. Jakarta : Rineka Cipta

Miles, M.B. \& Huberman, M. (2005). Qualitative Data Analysis (terjemahan). Jakarta : UI Press.

Mulyadi. (2008). Diagnosis Kesulitan Belajar. Yogyakarta: Nuha Litera

Mulyadi. (2010). Diagnosis Kesulitan Belajar \& Bimbingan Terhadap Kesulitan Belajar Khusus. Yogyakarta: Nuha Litera.

Slameto. (2003). Belajar dan Faktor-faktor yang mempengaruhinya. Jakarta: Rineka Cipta.

Sugiyanto. (2007). Psikologi Pendidikan Diagnostik Kesulitan Belajar (DKB). Yogyakarta: Universitas Negeri Yogyakarta.

Sugiyono. (2010). Metode Penelitian Pendidikan Pendekatan Kuantitatif, kualitatif, dan RED. Bandung: Alfabeta.

Syah, M. (2012). Psikolgi Pendidikan dengan Pendekatan Baru. Jakarta: PT. Rineka Cipta.

\section{Competing interests:}

The authors declare that they have no significant competing financial, professional or personal interests that might have influenced the performance or presentation of the work described in this manuscript. 